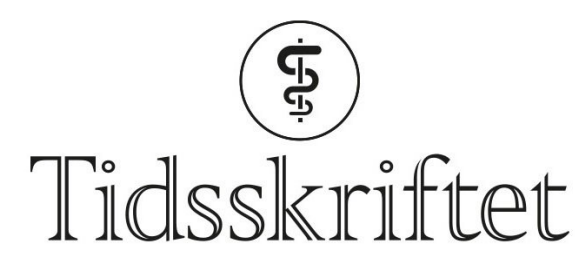

DEN NORSKE LEGEFORENING

\title{
Thoralf Christoffersen
}

MINNEORD

FINN OLAV LEVY

JAN-BJØRN OSNES

TOR SKOMEDAL

ÅSMUND REIKVAM

IVAR PRYDZ GLADHAUG

HEGE THORESEN

JØRG MøRLAND

Thoralf Christoffersen døde 29.10.2018, 77 år gammel. Farmakologisk institutt, Det medisinske fakultet og Universitetet i Oslo har mistet en sentral medarbeider og faglig inspirator gjennom over 40 år.

Han ble født i Oslo 17.7.1941 og vokste opp i Sarpsborg. Som medisinstudent var han forskerrekrutteringsstipendiat ved Institutt for medisinsk biokjemi, Universitetet i Oslo. Etter medisinsk embetseksamen i 1967 og turnustjeneste var han fra 1971 knyttet til Farmakologisk institutt, som forskningsstipendiat (NAVF) og universitetsstipendiat i årene 1971-74. Han disputerte for den medisinske doktorgrad i 1975 med avhandlingen Cyclic AMP Metabolism in Rat Liver During Normal and Neoplastic Development. Etter vikariater i 1975-80 fikk han fast stilling som dosent fra 1981 og professor fra 1985, til han ble professor emeritus i 2011.

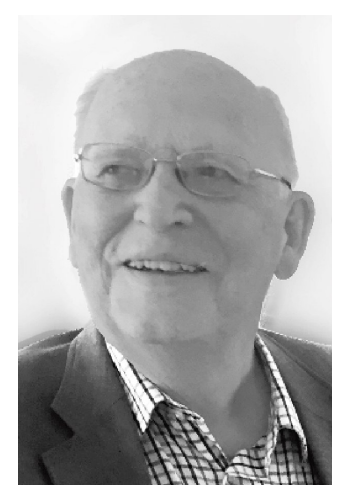


Thoralf Christoffersens faglige arbeid var preget av kvalitet, grundighet, tålmodighet, systematikk og profesjonalitet. Han var undervisningsleder i farmakologi i en lang periode, fagmiljøleder i årene 1993-2004, og koordinerte de obligatoriske prosjektoppgavene for medisinstudenter ved Det medisinske fakultet i mange år. Han fremhevet grunnleggende kunnskap som nødvendig for forståelsen og anvendelsen av legemidler. Derfor så han opprettelsen av Avdeling for farmakologi ved Oslo universitetssykehus som viktig.

Hans forskningsfelt - cellulær signaloverføring, regulering av cellevekst og kreftutvikling var grunnleggende for moderne kreftbehandling. Han veiledet en rekke doktorgradsstipendiater og studenter. Han var dyktig til å formidle faget i undervisning, tallrike forskningsartikler og bokkapitler om legemidler. Han var en mangeårig og sentral bidragsyter til Norsk Legemiddelhåndbok. Han tok initiativ til og ledet arbeidet med Cytostatikaboken, et standardverk for medikamentell kreftbehandling gitt ut i 8 utgaver.

Personlig var Thoralf både kunstner og humorist. Han laget pedagogiske illustrasjoner til sine presentasjoner og tegnet karikaturer av medarbeidere til stor glede ved sosiale samlinger. Han var glad i kunst, elsket musikk og spilte selv piano. Han var en svært klok og omsorgsfull mann som venner og kolleger alltid hadde glede og nytte av å konsultere.

Det gjorde sterkt inntrykk da han for mer enn ti år siden fortalte at han hadde alvorlig, uhelbredelig kreft. Med god behandling fortsatte han sin faglige aktivitet tross etter hvert store komplikasjoner. Han holdt god kontakt med kolleger i vanskelige sykdomsperioder med operative inngrep, og han var optimistisk like til det siste.

Thoralf Christoffersen har betydd mye for norsk farmakologi. Han har satt dype spor etter seg. Våre tanker går til nærmeste familie når vi nå i takknemlighet vil hedre ham og lyse fred over hans minne.

Publisert: 28. januar 2019. Tidsskr Nor Legeforen. DOI: 10.4045/tidsskr.18.ogoo

(C) Tidsskrift for Den norske legeforening 2020. Lastet ned fra tidsskriftet.no 